Л. С. Козуб

\title{
РЕЗУЛЬТАТИ ЕКСПЕРИМЕНТАЛЬНОГО ДОСЛДЖЕННЯ ПРОСОДІЇ АНГЛІЙСЬКОЇ РЕКЛАМИ, ОРІЄНТОВАНОЇ НА АДРЕСАТА 3 СЕРЕДНІМ СОЦІАЛЬНИМ СТАТУСОМ
}

Козуб Л. С. Результати експериментального дослідження просодії англійської реклами, орієнтованої на адресата з середнім соціальним статусом.

У статті представлені результати експериментально-фонетичного дослідження особливостей просодичної організації англійських телерекламних текстів, орієнтованих на адресатів із середнім соціальним статусом. У роботі описано варіантні реалізації аналізованих текстів. Особлива увага звертається на інваріант інтонаційної моделі телевізійної реклами, а також відповідні зміни просодичних параметрів, зумовлені функцію зазначених текстів.

Ключові слова: телевізійна реклама, інтонаційна модель, просодичні параметри, інваріант, соціальний статус адресата. 
Козуб Л. С. Результаты экспериментального исследования просодии английской рекламы, ориентированной на адресата со средним социальным статусом.

В статье представлены результаты экспериментально-фонетического исследования особенностей просодической организации английских телерекламных текстов, ориентированных на адресатов со средним социальным статусом. В работе описано вариантные реализации анализируемых текстов. Особое внимание обращается на инвариант интонационной модели телевизионной рекламы, а также соответствующие изменения просодических параметров, обусловленные функцией указанных текстов.

Ключевые слова: телевизионная реклама, интонационная модель, просодические параметры, инвариант, социальный статус адресата.

Kozub L. S. Results of experimental research of prosodic peculiarities of English commercials addressed to the recipients with medium social status.

The article deals with the results of the experimental research of the peculiarities of the prosodic organization of English television commercials addressed to the recipients with medium social status. It describes the variant realizations of the analyzed texts. A special tribute is paid to the invariant of the intonation model of television commercials as well as to the relevant changes of prosodic parameters stipulated by the function of the texts.

Key words: television commercials, intonation model, prosodic parameters, invariant, social status of recipients.

Сучасний етап розвитку лінгвістики характеризується поглибленим вивченням проблеми адекватного інтонаційного оформлення усного мовлення, складовою частиною якої є питання просодичної організації англійської комерційної реклами як частини загальної проблеми актуалізації інформаційного тексту.

Закономірностям функціонування телереклами як складного, багатопланового та досить поширеного явища присвячено роботи вітчизняних і зарубіжних авторів, у яких наведено загальний опис телерекламних текстів із погляду ефективності реалізації їхньої функції (І. А. Гольман, Д. Денісон, Н. С. Добробабенко, А. Кромптон, Л. Тобі), аналіз специфіки соціально-психологічного спрямування та ефективності впливу телерекламних текстів (У. Ф. Аренс, К. Л. Бове, К. В. Дорменко) та результати вивчення їхніх структурнопрагматичних особливостей (Ю. К. Баженов, Ф. Г. Панкратов, Т. М. Серьогіна).

На сьогодні лінгвістикою як наукою, $з$ одного боку, вироблено знання щодо соціально-психологічного та прагматичного спрямування телерекламних текстів, особливостей їхньої структури й ефективності реалізації їхньої функції, і водночас, з іншого, - фонетична наука ще не має у своєму розпорядженні досить повних теоретичних уявлень ๔ Л. С. Козуб, 2014. 
про характер та соціолінгвістичні особливості взаємодії просодичних підсистем в актуалізації англійських комерційних телерекламних текстів.

Мета цієї праці полягає в обгрунтуванні основних закономірностей просодичного оформлення англійських телерекламних текстів, орієнтованих на адресата 3 середнім соціальним статусом, шляхом проведення відповідного аудитивного аналізу.

Дослідження соціолінгвістичної специфіки телерекламних текстів засвідчило, що ефективний вибір мовних засобів телереклами має спиратися на передбачення належності реципієнтів до певної соціальної групи або професії, рівня їхньої освіти тощо та сприяти встановленню максимально довірливих стосунків із адресатом, впливаючи на певний рольовий набір особистості через окремі рольові сегменти, спільні для всіх індивідів, які складають конкретну аудиторію.

Аналітичне виокремлення таких найбільш значущих факторів, як: неоднорідніть адресатів повідомлення, їхній інтелектуальний рівень, тобто рівень освіти і культури, а також соціально-професійний статус, вік, стать тощо із усієї множини соціокультурних ознак, відомих 3 лінгвістичних джерел, дало змогу диференціювати споживачів реклами за трьома узагальненими ознаками їхнього соціального статусу на: високий, середній, низький.

Експериментальне визначення соціолінгвістичних особливостей просодичної організації текстів англійської комерційної телереклами здійснювалося відповідно до комплексної програми й методики дослідження. Основою для їхньої розробки слугувала класифікація функціональних, соціолінгвістичних та структурно-прагматичних ознак текстів англійської комерційної телереклами обгрунтована у праці [2, с. 210]. Усі інтонаційні параметри описані у цій статті вимірювалися й обраховувалися відповідно до традиційних методик обробки й узагальнення результатів аудитивного аналізу, викладених у джерелах [1, с. 206; 3, с. 212; 4].

Результати експериментального дослідження особливостей актуалізації типів термінального тону телерекламі, спрямованій на адресата з середнім соціальним статусом, відображено в Таблиці 1. 
Частота актуалізації термінального тону (\%)

\begin{tabular}{|c|c|c|c|c|c|c|c|c|c|c|c|c|c|}
\hline \multirow{2}{*}{\multicolumn{2}{|c|}{ Характеристики тексту }} & \multicolumn{12}{|c|}{ Тип термінального тону \% } \\
\hline & & \multicolumn{3}{|c|}{ спадний } & \multicolumn{3}{|c|}{ Висхідний } & \multicolumn{3}{|c|}{ рівний } & \multirow{2}{*}{ 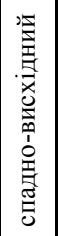 } & \multirow{2}{*}{ 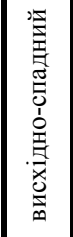 } & \multirow{2}{*}{ 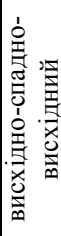 } \\
\hline $\begin{array}{c}\text { Трива- } \\
\text { лість } \\
\text { звучання }\end{array}$ & $\begin{array}{c}\text { Структурні } \\
\text { компоненти }\end{array}$ & 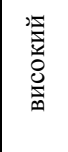 & 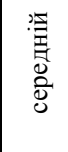 & 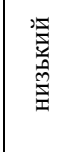 & 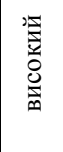 & 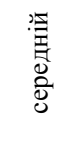 & 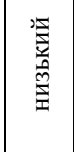 & 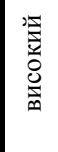 & 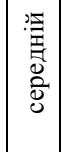 & 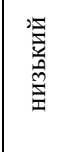 & & & \\
\hline \multirow{3}{*}{ Мала } & Початок & 5,55 & 61,11 & 0,00 & 5,56 & 5,56 & 11,11 & 0,00 & 0,00 & 0,00 & 0,00 & 11,11 & 0,00 \\
\hline & Основна частина & 14,19 & 52,26 & 13,55 & 0,65 & 9,03 & 7,74 & 0,00 & 1,29 & 0,00 & 1,29 & 0,00 & 0,00 \\
\hline & Завершення & 24,00 & 40,00 & 0,00 & 0,00 & 4,00 & 32,00 & 0,00 & 0,00 & 0,00 & 0,00 & 0,00 & 0,00 \\
\hline \multirow{3}{*}{ Середня } & Початок & 4,21 & 56,84 & 17,90 & 0,00 & 10,53 & 5,26 & 0,00 & 1,05 & 1,05 & 1,05 & 2,11 & 0,00 \\
\hline & Основна частина & 19,47 & 45,84 & 9,38 & 3,72 & 10,97 & 5,49 & 0,00 & 1,06 & 0,18 & 0,71 & 3,18 & 0,00 \\
\hline & Завершення & 11,64 & 43,83 & 8,22 & 1,37 & 23,97 & 7,53 & 0,69 & 0,00 & 0,00 & 0,00 & 2,06 & 0,69 \\
\hline \multirow{3}{*}{ Велика } & Початок & 0,00 & 55,56 & 11,11 & 0,00 & 0,00 & 33,33 & 0,00 & 0,00 & 0,00 & 0,00 & 0,00 & 0,00 \\
\hline & Основна частина & 0,00 & 63,27 & 10,20 & 0,00 & 4,08 & 18,37 & 0,00 & 2,04 & 0,00 & 0,00 & 2,04 & 0,00 \\
\hline & Завершення & 0,00 & 45,46 & 18,18 & 0,00 & 0,00 & 27,27 & 0,00 & 9,09 & 0,00 & 0,00 & 0,00 & 0,00 \\
\hline
\end{tabular}

Таблиця показує, що спадний середній термінальний тон iз частотністю від 40,00\% до 63,27\% домінує в усіх трьох різновидах телереклами: малій, середній і великій. Неконтрастність відмінностей можна також простежити у використанні другого за частотою термінального тону. Так, у телерекламі малої тривалості це висхідний низький і висхідно-спадний тони (по 11,11\%) на початку тексту, спадний високий $(14,19 \%)$ в основній частині та висхідний низький $(32,00 \%)$ у завершенні. У середній за тривалістю звучання телерекламі другим за частотою використання є спадний низький термінальний тон $(17,90 \%)$ на початку телерекламного повідомлення, спадний високий $(19,47 \%)$ в його основній частині та висхідний середній $(23,97 \%)$ у завершенні. У телерекламі великої тривалості звучання 3 меншою часткою порівняно зі спадним середнім тоном вживається висхідний низький термінальний тон, який складає 33,33\% на початку, $18,37 \%$ в основній частині та $27,27 \%$ у завершенні.

๑ Л. С. Козуб, 2014.

-92 - 
Отже, порівнюючи телерекламу різної тривалості звучання очевидно, що найбільша варіативність термінальних тонів простежується в усіх структурних компонентах телереклами середньої тривалості. Крім того, у цій рекламі найповніше подані складні тони: спадно-висхідний, висхідно-спадний і висхідно-спадно-висхідний.

Специфіку розподілу частот актуалізації різновидів тонального діапазону інтоногрупи відображено в Таблиці 2.

Таблиця 2

Частота актуалізації тонального діапазону інтоногрупи (\%)

\begin{tabular}{|c|c|c|c|c|c|c|}
\hline \multicolumn{2}{|c|}{ Характеристики тексту } & \multicolumn{5}{|c|}{ Тональний діапазон інтоногрупи \% } \\
\hline $\begin{array}{l}\text { Тривалість } \\
\text { звучання }\end{array}$ & $\begin{array}{c}\text { Структурні } \\
\text { компоненти }\end{array}$ & широкий & розширений & середній & звужений & вузький \\
\hline \multirow{3}{*}{ Мала } & Початок & 5,55 & 27,78 & 50,00 & 16,67 & 0,00 \\
\hline & Основна частина & 12,90 & 12,90 & 56,13 & 16,77 & 1,29 \\
\hline & Завершення & 24,00 & 12,00 & 60,00 & 4,00 & 0,00 \\
\hline \multirow{3}{*}{ Середня } & Початок & 5,26 & 31,58 & 46,31 & 14,74 & 2,11 \\
\hline & Основна частина & 22,30 & 24,60 & 36,11 & 16,11 & $\mathbf{0 , 8 8}$ \\
\hline & Завершення & 15,75 & 34,25 & 28,08 & 21,92 & 0,00 \\
\hline \multirow{3}{*}{ Велика } & Початок & 0,00 & 11,11 & 77,78 & 11,11 & 0,00 \\
\hline & Основна частина & 0,00 & 14,29 & 75,55 & 8,16 & 0,00 \\
\hline & Завершення & 0,00 & 18,18 & 81,82 & 0,00 & 0,00 \\
\hline
\end{tabular}

Аналіз даних таблиці свідчить, що найчастотнішим діапазоном інтоногрупи в телерекламі малої, середньої та великої тривалості $€$ середній діапазон, який домінує в усіх структурних компонентах текстів за винятком завершення тексту середньої за тривалістю звучання телереклами, де превалює (34,25\%) розширений діапазон за меншої $(28,08 \%)$ частки середнього.

Другий за частотою - розширений діапазон трапляється на початку телереклами малої $(27,78 \%)$ й середньої $(31,58 \%)$ тривалості, в основній частині середніх $(24,60 \%)$ і великих (14,29\%) текстів та в завершенні телереклами великої $(18,18 \%)$ тривалості звучання. В основній частині малих за тривалістю текстів другим за частотністю вживання $\epsilon$ звужений $(16,77 \%)$ діапазон, а в завершенні цих текстів - широкий (24,00\%). Початок телерекламних текстів великої тривалості поданий

$$
-93 \text { - }
$$

с С. С. Козуб, 2014. 
однаковою (по 11,11\%) часткою розширеного й звуженого діапазонів.

Результати аналізу варіювання висотнотональних рівнів початку і завершення інтоногрупи в текстах відображено в Таблиці 3.

Таблиця 3

\begin{tabular}{|c||c|c|c|c|c|c||c|c|c|c|c|}
\hline Частота актуалізації тонального рівня початку й завершення \\
інтоногрупи (\%)
\end{tabular}

За даними таблиці, найбільшою варіативністю тональних рівнів оформлення початків інтоногруп характеризуються малі й середні за тривалістю звучання телерекламні тексти. Так, у телерекламі малої тривалості початок поданий однаковою (по 33,33\%) часткою середнього підвищеного i низького рівнів за меншої $(22,22 \%)$ кількості середнього зниженого. В основній частині домінує $(40,65 \%)$ низький тональний рівень, а частка середнього зниженого складає $29,03 \%$. Завершення тексту відзначається превалюванням $(56,00 \%)$ середнього зниженого рівня початку інтоногрупи. Менш рекурентним $(16,00 \%)$ є середній підвищений рівень.

๑ Л. С. Козуб, 2014.

- 94 - 
На початку телереклами середньої тривалості зареєстровано 38,95\% актуалізації середнього зниженого тонального рівня. Щодо основної частини, то тут приблизно з однаковим відсотком вживаються середній знижений $(29,56 \%)$, середній підвищений $(26,90 \%)$ і низький $(24,96 \%)$ рівні. Завершення тексту подане превалюванням $(36,99 \%)$ середнього підвищеного тонального рівня з меншою часткою $(30,82 \%)$ середнього зниженого.

Менша варіативність тонального рівня початку інтоногрупи притаманна текстам великої тривалості, початок і основна частина яких характеризуються домінуванням низького рівня (77,78\% i 48,98\% відповідно). Завершення ж у 72,73\% випадків оформляється середнім зниженим тональним рівнем за меншої $(27,27 \%)$ рекурентності низького.

Аналіз висотнотональних рівнів завершення інтоногрупи свідчить про домінування низького рівня в усіх структурних компонентах текстів малої, середньої та великої тривалості. Другим за частотою використання є здебільшого середній знижений рівень, презентований $36,00 \%$ у завершенні текстів малої тривалості, $12,63 \%$ на початку й $10,80 \%$ в основній частині текстів із середньою тривалістю, а також $11,11 \%$ на початку, 24,49\% в основній частині та $36,36 \%$ у завершенні великих за тривалістю звучання текстів.

Опис результатів аналізу особливостей актуалізації інтервалу тональних рівнів на стиках структурних компонентів тексту телереклами наведено в Таблиці 4.

За даними таблиці, у малих за тривалістю телерекламних текстах на стику початку та основної частини домінує $(37,50 \%)$ позитивний звужений інтервал. Меншою (по 25,00\%) часткою представлені негативний розширений i середній інтервали та позитивний розширений інтервал, який складає 12,50\%. Оформлення стику основної частини і завершення також маркується максимальним $(62,50 \%)$ використанням позитивного звуженого інтервалу, а також рівномірним (по 12,50\%) розподілом позитивного середнього, негативного середнього та нульового інтервалів.

У середніх за тривалістю звучання телерекламних текстах простежується превалювання $(41,67 \%)$ позитивного звуженого інтервалу на стику початку та основної частини за меншого $(20,83 \%)$ використання позитивного середнього інтервалу. Подібним чином актуалізується інтервал і на стику основної частини та завершення. Цій ділянці також властиве переважання (32,14\%) позитивного звуженого 
інтервалу. Крім того, тут зареєстровано приблизно однакові частки актуалізації позитивного розширеного (25,00\%) та негативного звуженого (21,43\%) тональних інтервалів.

Таблиця 4

Частота актуалізації інтервалу тональних рівнів на стиках структурних компонентів телерекламного тексту (\%)

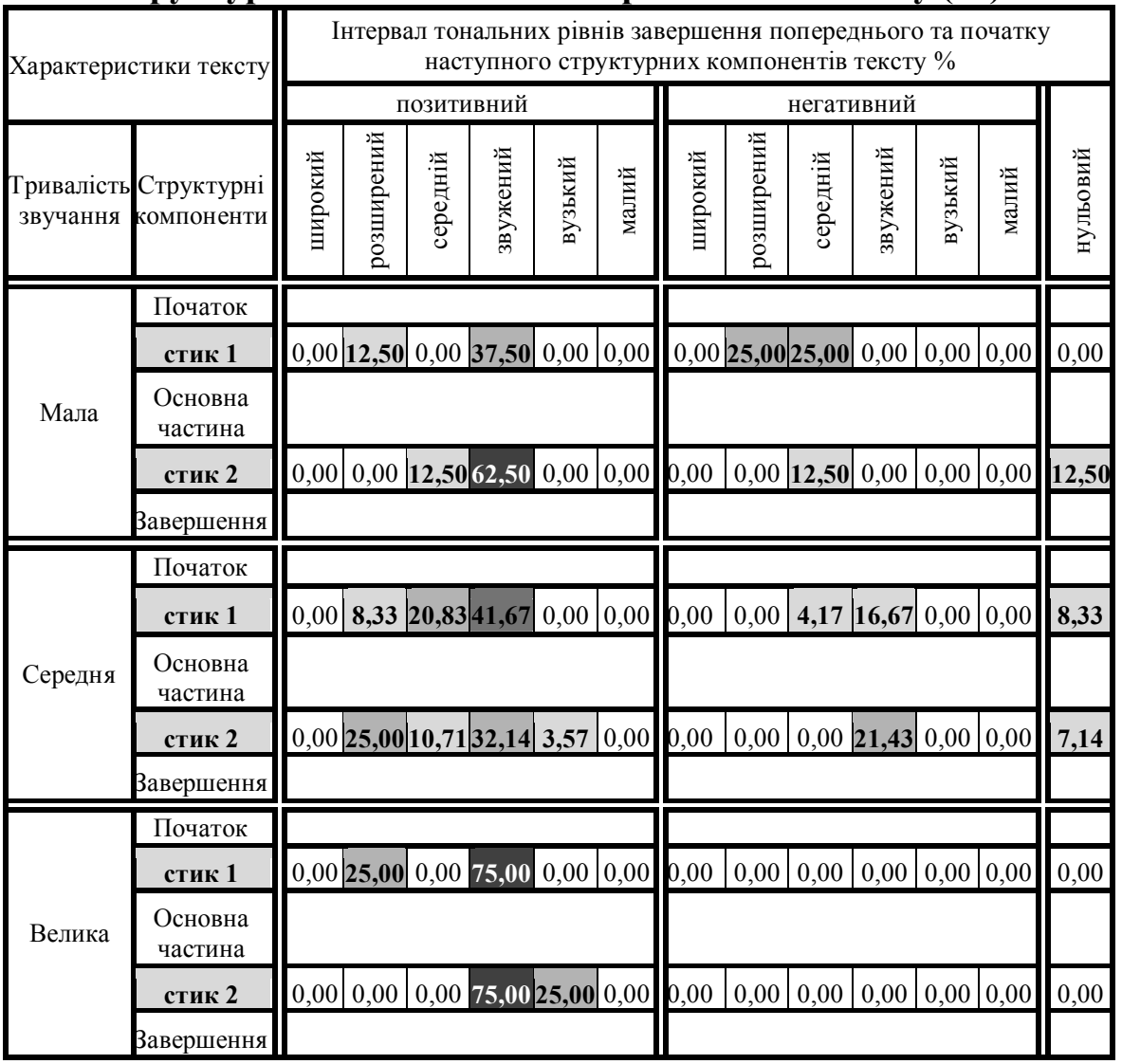

Аналізом установлено, що зазначена варіативність актуалізації інтервалів стиків структурних компонентів телерекламних текстів малої i середньої тривалості виникає внаслідок змін і функціонального спрямування окремих структурних елементів та їхнього емоційнопрагматичного потенціалу. Щодо телереклами великої тривалості звучання, то в ній на стиках початку і основної частини та основної ๑) Л. С. Козуб, 2014. 
частини i завершення домінує (по 75,00\%) позитивний звужений інтервал за меншої частки позитивного розширеного $(25,00 \%)$ на стику початку й основної частини та позитивного вузького $(25,00 \%)$ на стику основної частини і завершення.

Аналіз частоти актуалізації інтервалу «передтакт - такт» показує, що в телерекламі малої і середньої тривалості звучання найчастотнішим інтервалом є позитивний вузький, який у малих за тривалістю текстах переважає на початку $(58,33 \%)$ та в завершенні $(55,56 \%)$, а в середніх в основній частині $(57,58 \%)$ та в завершенні $(48,08 \%)$. До того ж в основній частині тексту малої тривалості та на початку телереклами 3 середньою тривалістю зафіксовано переважання позитивного звуженого інтервалу. Великі за тривалістю звучання тексти марковано переважанням позитивного звуженого інтервалу в усіх їхніх структурних компонентах (75,00\% на початку і в завершенні, 65,52\% в основній частині). Незначна частка інших різновидів інтервалу «передтакт - такт» актуалізується в позитивній розширеній і середній, негативній звуженій і вузькій та нульовій зонах.

Щодо інтервалу «передтермінальна частина - ядро», то тут у всіх структурних компонентах малих та середніх за тривалістю телерекламних текстів та на початку і в основній частині текстів великої тривалості домінує негативний вузький інтервал, який варіює від 46,67\% до $61,29 \%$. Винятком є лише завершення великих за тривалістю текстів, де найчастотнішим $(50,00 \%) \epsilon$ негативний звужений інтервал. Більша варіативність притаманна менш частотним за вживанням інтервалам.

Результати розподілу частоти актуалізації темпу в телерекламних текстах, розрахованих на адресата середнього соціального статусу, свідчать про чітке переважання помірного темпу в межах усіх без винятку структурних компонентах текстів різної тривалості звучання $(84,00-$ 94,44\% у текстах малої тривалості звучання; 84,96 - 93,15\% у текстах середньої тривалості; 77,78 - 95,92\% у текстах великої тривалості).

Тексти, призначені для адресатів із середнім соціальним статусом, характеризуються превалюванням заповнених короткої та перцептивної пауз. Найбільш рекурентними в малій за тривалістю звучання телерекламі є перцептивні заповнені паузи, які в 27,78\% випадків зареєстровано на початку тексту, у $36,00 \%$ реалізацій у його основній частині та в 28,00\% - у завершенні. Подібне вживання пауз зафіксоване й у телерекламі середньої і великої тривалості, де в усіх структурних компонентах тексту найчастотнішою $є$ перцептивна заповнена пауза за 
меншої рекурентності короткої заповненої.

Аналіз частоти актуалізації гучності в телерекламі, призначеній для адресатів із середнім соціальним статусом, показав, що найбільш типовою в малій, середній та великій за тривалістю звучання телерекламі $\epsilon$ помірна гучність, яка варіює від $32,04 \%$ до $81,82 \%$ у межах різних структурних компонентів тексту. Винятком є завершення телереклами середньої тривалості, де домінує (47,26\%) підвищена гучність.

Узагальнення викладених вище результатів дає змогу стверджувати, що диференційними ознаками, які дозволяють вирізнити варіантну реалізацію просодичного оформлення тексту англійської телереклами, призначеного для адресатів із середнім соціальним статусом, $є$ такі типові ознаки: спадний середній тип термінального тону, середній тональний діапазон інтоногрупи, середній знижений або низький висотнотональний рівень початку інтоногрупи, низький висотнотональний рівень завершення синтагми, перцептивні й короткі заповнені паузи, помірна та підвищена гучність, помірний темп, звужений або вузький позитивний інтервал «передтакт - такт», вузький негативний інтервал «передтермінальна чатина - ядро», позитивний звужений інтервал тональних рівнів на стику початку та основної частини й на стику основної частини та завершення тексту.

На основі обробки й узагальнення результатів експериментальнофонетичного дослідження закономірностей просодичного оформлення англійських телерекламних текстів, призначеного для адресатів із середнім соціальним статусом, установлено такий інваріант їхньої інтонаційної моделі: варіювання типу термінального тону від спадного високого до висхідного низького; зміни тонального діапазону інтоногрупи в межах від розширеного до звуженого; актуалізація висотнотонального рівня початку інтоногрупи в межах від низької та середньої підвищеної зон за відповідного варіювання від низької до середньої підвищеної зон висотнотональних рівнів іiі завершення; зміщення гучності від помірної до високої в малих i середніх за тривалістю звучання текстах.

Результати, отримані під час здійснення експериментальнофонетичного дослідження, можуть бути ефективно використані під час подальшого поглибленого вивчення соціолінгвістичної специфіки актуалізації англійських телерекламних текстів. 


\section{Література}

1. Калита А. А. Фонетичні засоби актуалізації смислу англійського емоційного висловлювання : монографія / А. А. Калита. - К. : Вид. центр КДЛУ, 2001. - 351 с.

2. Козуб Л. С. Систематизація лінгвістичних ознак текстів англійської комерційної телереклами / Л. С. Козуб // «Гуманітарний вісник» Черкаського державного технологічного університету. Серія : Іноземна філологія. - 2004. - № 8. - С. 210-213.

3. Тараненко Л. Актуалізація англійських прозових фольклорних текстів малої форми : монографія / Л. Тараненко. - К. : Кафедра, 2014. - 288 с.

4. Федорів Я. Р. Соціокультурні аспекти просодичної організації висловлюваньневдоволень (експериментально-фонетичне дослідження) : дис. ...канд. філол. наук / Я. Р. Федорів. - К., 2000. -248 с.

Стаття надійшла до редакиії 30.10.2014 p. 